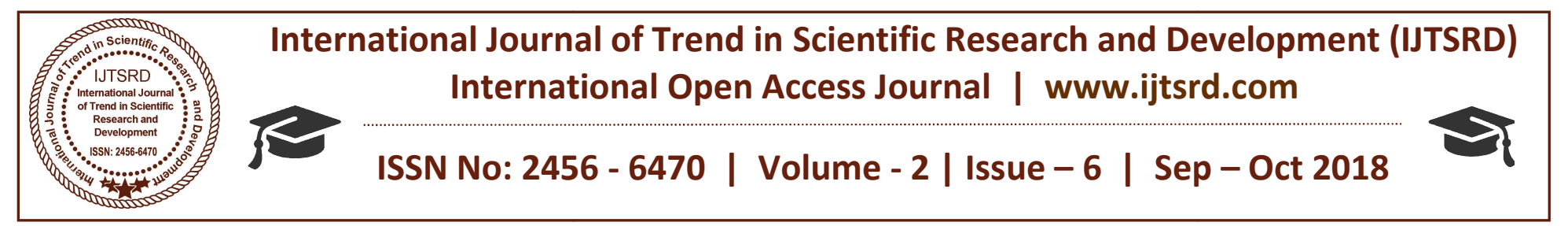

\title{
Towards the Utilisation of Technologies in Curbing Examination Misconduct in a Nigerian University
}

\author{
Dr. Peter Ajelabi Ph.D \\ Associate Professor, Faculty of Education, Yusuf Maiatamasule University, Kano, Nigeria
}

\begin{abstract}
Examination misconduct has consistently remained the bane of Nigeria's educational system. This cuts across all the educational sectors, including the tertiary. This paper examined the concept of educational misconduct, and the various types that were listed in two state-owned Universities in Northern Nigerian Students' Handbook. It goes further to highlight those forms of examination misconducts that resulted from the development of technologies. Majority of current examination misconduct cases were those that involves the usage of technologies, most especially, the mobile phones. The paper further examined various measures that the University has put in place to curb examination misconduct. However, these measures have yielded little or no positive result. This paper therefore highlighted various technologies that can be used to minimise or possibly eradicate examination misconduct issues. The challenges associated with the integration were discussed. The prospects were also enumerated. The paper further highlighted how some of these technologies could be incorporated and effectively used to curb examination misconducts in the University. Suggestions were made on how to achieve these. This paper concluded by hypothesising that if technologies are adopted to curb examination misconducts, the quality and standard of education would be enhanced.
\end{abstract}

Keyword: Utilisation, Technologies, Examination Misconduct, Nigeria, University

\section{INTRODUCTION}

The conduct of examinations is one of the major measures and most practical way of determining the extent to which students have achieved, in a particular course of instruction or study. Consequently, since the introduction of formal education into the Nigerian educational system, the conduct of examinations still remains, as the necessary tool for an objective assessment and evaluation of what students have achieved after a particular period or semester, as the case may be. Despite other various searches to measure students' achievement and ability in a particular task or skill, none has been found suitable to achieve this desired goal, without giving consideration to the adoption of examinations as the best option.

At every stage of students' educational attainment in a formal educational system, they are compelled to sit for one examination or the other, before moving to the next level (Ajelabi, 2018). This is likely to be the case until the student obtains the highest academic qualifications in life, which is a Doctor of Philosophy (Ph.D) certificate. In essence, sitting for examinations is inevitable for somebody in a formal education system.

An examination can be viewed as a formal test that is designed to assess the test-takers knowledge, skills, attitude, aptitude, physical fitness etc on various topics, courses or fields of specialisation. Sitting for examinations have always been a burden on students. Most of them do not look forward to examination periods. This is because they do go through so much pressure during examinations. In most cases, their preparations always seem to fall short of the expectations from the examiners.

Formal education system in Nigeria is plagued with many problems. These problems include shortage of qualified teachers, fall in the standard of education, overcrowded classrooms, laziness on the part of teachers and students, inadequate inspection and supervision, poor attitude to work, examination 
misconducts, poor funding and dilapidated classrooms among others. Prominent among these is the issue of examination misconduct.

Examination misconduct (malpractice) is not a new phenomenon in Nigeria. One can say that the problem of examination misconduct is old as the introduction of Western education into the nation (Maduemeza, 1998). She goes further to state that the first officially recorded examination malpractice or misconduct in Nigeria occurred in 1914, during the Senior Cambridge Local Examination paper, which was leaked before the scheduled date of examinations. In essence, the menace of examination misconduct in Nigeria has spanned over 100 years.

For a very long time, the issue of examination misconduct had been one of the vices troubling educational system in Nigeria of today (Anzare, 2014). From the East to the West, North to the South, the menace of examination misconduct is echoed in all the nooks and crannies of Nigeria. Some people see it as a monster that is beyond ordinary human perception and a distracting evil which places stigma on the educational system.

Examination misconduct has continued to grow at all levels of the national educational system. It usually start from the kindergarten or pre- nursery stage, move gradually to the primary level, then become worse at the junior secondary school, and reaches the peak at the terminal Senior Secondary School Certificate/ National Examinations Council of Nigeria Examinations / Joint Admissions and Matriculations Board Examinations stages. At this terminal examinations level, some students, parents and guardians are always very desperate and willing to do anything (including involvement in examinations misconduct) to ensure that their candidates come out in flying colours. This is more pronounced during the period when these final examinations, are being conducted, as well as when the candidates are sitting for examinations so as to secure admissions into the tertiary educational system.

The above situation and circumstances has been a continual dilemma, to the extent that The Federal Government of Nigeria had to promulgate some decrees and sanctions to punish offenders. In 1984, there was the promulgation of Decree 20 by the military government to deal with the menace. It states that any person who fraudulently or with intent to cheat or secure any unfair advantage to himself, and produces, sells or buys any question paper intended for an examination, shall be guilty of that offence, and on conviction, be sentenced to twenty one years imprisonment, without the option of a fine. Also, in 1999, Decree number 33 was promulgated. It was tagged Examinations Malpractice Act of 1999. It is an act to create offences relating to examinations malpractices and to prescribe penalties for such offences. According to the Act, cheating at examinations, stealing of question papers, impersonation, obstruction of supervisor, forgery of result slip and conspiracy, among others were seen as constituting examinations misconduct. The decree goes further to state the punishment to be accorded to offenders. For example, a person under 18 years, who is alleged to be involved in cheating during an examinations, and is proved guilty in the law court, is expected to pay a fine of up to $\mathrm{N} 100,000$ (one hundred thousand naira ) only, or be sentenced to a jail term, not exceeding three years, or both. If a Principal or an Agent is involved, it is a term, not exceeding four years, without the option of a fine. However, up till date, little or nothing has been heard regarding the implementation of this decree.

Furthermore, examinations misconduct matter has become a topical issue among researchers due to its prominent nature. Ijaiya (2004), Issa (2006) and Ndifon (2012) among others have looked at examination malpractice both in the school environment and public examinations. Their findings showed that it has proved to be an incurable disease in the educational system, thereby making nonsense of the educational quality. They were also of the view that it has been a continual dilemma and, cuts across the whole educational system from primary to tertiary educational level.

What is more alarming is the findings of Ndifon(2012), where he reported that "Nigeria was ranked as number one in the World's Examination Malpractice index in 2011". This is quite worrisome and pathetic. Hence, a need of concern for Nigerian academics and researchers in this specialism or related field, to provide long lasting solution to the ugly situation at hand.

\section{CONCEPT OF EXAMINATION MISCONDUCT}

As observed earlier, examination misconductis a cankerworm that has eaten deep into the society, and 
portends grave danger for the nation. It is among the serious problems that is plaguing our educational system nowadays.

Various researchers have defined examinations misconduct from different views and angles. Onuka and Amusan (2008) defined examination malpractice (misconduct) as 'any dishonest and unauthorised action or deed committed by a student on his own or in collaboration with others like fellow students, guardians, parents, teachers, head teachers, examinations officers, supervisors, invigilators, printers, security officers, and, any group of people, before, during, or, after examinations in order to obtain undeserved marks or grades'.

Furthermore, Awanbor (2004) gave a definition similar to that of Onuka and Amusan (2008) that was stated above. In his own view, examination malpractice (misconduct) is considered to be ' an illegal act committed by a single student, or, in collaboration with others like fellow students, parents, teachers, supervisors, invigilators, computer operators, secretarial staff, or anybody or group of people , before, during, or, after examinations, in order to obtain undeserved marks or grades'

Looking at the above definitions critically, one can deduce that:

A. Examinations misconduct is an illegal behaviour

B. The act is carried out deliberately or intentionally

C. It can involve a single student or groups of students

D. Accomplices can be involved e.g supervisors, teacher, parents, secretarial staff etc

E. It can take place before, during, and after examinations

F. The major mission for getting involved in examination malpractice is to obtain undeserved marks or grades.

In a nutshell, examinations misconduct is a short cut to attain success. Students embark on it to excel easily and cheaply. This has been the norm in presentday Nigerian society.

Onuka and Durowoju (2011) discovered that "examination malpractice (misconduct), rather than abated, is on the increase, in the African educational system, especially in Nigeria'.

\section{COMMON TYPES OF EXAMINATION MISCONDUCT IN NIGERIAN TERTIARY INSTITUTIONS}

It must be stated here that what constitutes examinations misconduct in all the Nigerian tertiary institutions are virtually the same or similar in nature. Based on this, this research would examine the content of what constitutes examinations misconduct in two state - owned Universities in North West Zone of Nigeria.

With reference to The Northwest University ( now Yusuf MaitamaSule University), Kano, Students' Handbook published in 2016, and that of Umaru Musa Yar"adua University, Katsina, also published in 2016, the following major categories of examinations misconduct / malpractices were identified : impersonation, exchanging names and numbers on answer scripts, introduction and use of relevant unauthorised materials in the examinations hall, exchange of materials, illegal removal of examinations scripts, copying from another candidate, cheating outside the examination hall.

Others include using mobile phones and other ICT devices to access voice or text messages, documents, materials from the internet etc, destruction of exhibits and others deemed by The Senate Committee on Examinations Malpractice.

\subsection{Revolutionised Examination Misconduct}

The advancement in technology has truly affected every sector of our lives, both positively and negatively. Examination misconduct has long graduated from the normal 'giraffing' at a neighbor's work to more advanced and sophisticated systems. Massive applications of Information, Communications and Technology (ICT) have added new dimensions to the forms of examinations misconduct. Nnechi (2006) reported that the rapid growth of digital technologies and their integration in education have given many students new tools to facilitate cheating. Curan, Middleton and Doherty (2011) collaborated the above when they mentioned that 'the previous methods of cheating (traditionally) are speedily being replaced with miniature technologies, which can hold large amounts of information.

Candidates now employ the functionalities of these high digital technological devices to bring answers to the examinations hall. Among the technologies being 
used to perpetuate examination misconducts are mobile phones, electronic organisers, MP3 players, microscopic earphones, optical character recognition software, programmable calculator, palmtops and digital camera phones, among others.

Akpor and Akpor (2006) stressed that students use mobile phones to send information silently through text messages or faxing to friends. According to him, this is more pronounced in tertiary institutions. He reported further that in 2004/2005 session, many students of University of Agriculture, Makurdi were caught sending text messages of answers to friends, during examinations. In another study, Agbatogun (2007) discovered that fifteen students of MoshoodAbiola Polytechnic, Abeokuta were arraigned before the Students Disciplinary Commmittee for committing this same offence.

Nowadays, students stitch bluetooth device on their clothes. Bluetooth devices help candidates who are inside the examinations hall to stay connected with people or students who are outside the examinations hall. The candidates inside the hall would seek for answers to the questions been examined. Furthermore, MP3 is an ICT device whereby someone can put a whole lecture on it, and smuggle it into the examination hall. With electronic organiser, one can put an entire revision note in a hand-held organiser. In addition, microscopic earphones are wireless network device that students insert into their ears. Since it is wireless, students may perpetuate the act without being noticed. Also, optical character recognition software makes use of printed text that can be quickly inputed into a processor for 'doctoring'. It makes perfect copies of assignments in such a manner that one can hardly differentiate between the original and duplicate copy. Lastly, palmtops are handheld. It can be used to receive and make calls, take digital photos and record sounds.

Certainly, these gadgets are quite a better option for cheating in examinations. The chips provide limited information, whereas, the gadgets with internet are a comprehensive solution to examination questions. Using gadgets to cheat is seen as fun by students.

\section{CURRENT MEASURES ADOPTED BY THE UNIVERSITY TO CURB EXAMINATIONS MISCONDUCT}

In recent times, the Senate and the University Management have adopted and proposed various means to reduce minimise and eradicate the menace of examinations misconduct within the University system. These measures are the traditional ways that are common in most African Universities. Some of the steps taken by the University include:

$>$ Spacing of students in the examination hall

$>$ Allocation of average of one invigilator to fifty students in the examination hall

$>$ Use of Senior Academic member of staff to be the overall examinations supervisor

$>$ Level co-ordinators advising their students on examinations ethics

> The General Studies Program Unit organising talks on examinations ethics

- Faculties and Departments producing and displaying bill boards in conspicuous places advising against getting involved in examinations misconduct

Management and Information Science (MIS) Unit, displaying notices on the screen advising students to shun examinations misconduct

Use of security men to support invigilation

Faculties organising talks on Examinations misconduct

Students dropping bags/ belongings in front of the examination halls before students get seated

Invigilators giving last minute reminder on the need to comply with examinations regulations.

To ensure compliance with examination regulations, the University came up with different sanctions to be given to erring students. These vary from written warning, to rustication and expulsion from the University. These punishments are meted to students after they must have faced Departmental, Faculty and Senate Committees on Examinations Misconduct.

At the end of the day, the University displays the names of those found guilty on notice boards. However, it was further suggested that their names and pictures should be posted on the University's website. This last suggestion is yet to be implemented. It is disheartening to state that despite all these measures aimed at curbing examination misconduct in the University, it has yielded little or no fruit. In the last examinations, more than six students in a particular Department were involved in examination misconduct.

Below is the number of students who faced Senate Examinations Misconduct Committee at Yusuf 
MaitamaSule (formerly Northwest) University, Kano, according to Faculties, between 2013 and 2017

Table 1 Examinations Misconduct Cases Reported and Treated by Senate Examinations Misconduct Committee Between 2013 and 2017.

\begin{tabular}{|c|c|c|c|c|c|c|}
\hline Year & $\mathbf{2 0 1 3}$ & $\mathbf{2 0 1 4}$ & $\mathbf{2 0 1 5}$ & $\mathbf{2 0 1 6}$ & $\mathbf{2 0 1 7}$ & Total \\
\hline EDU & 1 & 2 & 10 & 14 & 13 & 40 \\
\hline SMS & 6 & 6 & 5 & 4 & 5 & 26 \\
\hline HUM & 3 & 1 & 8 & 4 & 8 & 24 \\
\hline BMS & -- & 1 & -- & 2 & 6 & 9 \\
\hline Science & 1 & 1 & 6 & 2 & 7 & 17 \\
\hline Total & 11 & 11 & 29 & 26 & 39 & 116 \\
\hline
\end{tabular}

Source Academic Secretary Office, Yusuf MaitamaSule University, Kano, Nigeria (2018)

From the report collected from same office, the information further revealed that $55.8 \%, 58.5 \%$, $63.5 \%, 66.4 \%, 70.3 \%$ of the cases treated in 2013 , 2014,2015, 2016 and 2017 respectively involved the use of technologies to perpetuate the illegal act. One can observe that there has been a marginal increase every year in the use of technologies to commit this evil act. This shows that the rate of the adoption of technologies to commit examination misconduct is on the increase. In addition, one would observe that the number of cases treated in 2015 was 29. However, it increased to 39 in 2017, though there was a decrease in 2016.

Since the use of traditional and manual means of reducing examinations misconduct has not yielded much result, it is therefore necessary to employ the use of technology in solving this problem.

\section{ADOPTION OF TECHNOLOGIES}

With the continuous repetition of examinations misconduct menace, adequate means ought to be taken to curtail this. This is because the cankerworm has had negative effects on the image, integrity and dignity of not only the staff and students working and studying in Nigerian tertiary institutions in general, but also that of Yusuf MaitamaSule University, Kano in particular.

In the last few years, most organisations and Examinations Bodies e.g. Joint Admissions and Matriculations Board (JAMB) and the West African Examinations Council (WAEC), as well as professional examination bodies have resorted to the adoption of technologies to minimise the menace of examinations misconduct. If this is the case, Nigerian Universities (including YMSUK), should not be swept away in this revolutionary stride. It must be stated that some Universities in Nigeria (since about 2010) have commenced the use of technologies (through the adoption of Computer Based Test examinations) to minimise examination misconduct. This CBT examination is normally adopted for post graduate qualifying examinations, as well as for other large class courses. However, we can go further to adopt the sophisticated technologies, as it is being practised in most Universities, located in China.

One of the major technologies that is presently being adopted to reduce examination misconduct is the use of Computer Based Test examinations. This is becoming more popular in Nigeria, and it is easy to use by both the students and the examiners. It does not cost much, when compared to paper-based examinations, particularly, when dealing with large classes like the General Studies courses.

Related to this is the installation of Closed Circuit Television (CCTV) system in the examination halls. CCTV is an electronic monitoring device, whereby from the control room, the examination monitoring officers would watch and monitor the examination hall effectively. An invigilator can do this effectively, irrespective of the number of students sitting for the examinations.

Similar to this is the use of remote-controlled terminals that are linked with the main server of the institution. This is an e-invigilation system that is stress free, and very effective

Furthermore, electronic detection devices could be provided and purchased for examination purpose. Depending on the capacity, the make and the quality, this magical equipment is sold as low as $£ 100$ to $£ 150$ (which is just about N47,000, with the current exchange rate) in the United Kingdom. It has the capacity to detect the presence and use of mobile phones.

Another main cheap technology that can be used for minimising examination misconduct is the use of hand held metal detectors during examinations. This reduces mass cheating. This equipment is used to frick candidates at examination centres before going inside the examination hall. This detector is used to check prohibited metallic/electronic 
devices/copper/aluminium/wire/

electronic gadgets/photovoltaic equipment or similar materials which the students wanted to bring in, that had been hidden inside his/her clothes. This equipment is highly sensitive to metals. The detector makes a beep sound on detecting a hidden metal device.

In the same vein, door frame metal detectors can be acquired for same purpose. These are fixed against the door frames. As the student crosses the door, the detector will make a beep noise if the student is carrying any gadget, device, mobile phone etc.

Lastly, phone signal jammer is another technology used to curb examination malpractice. It prevents radio equipment from receiving and transmitting signals. This is done by blocking all electrical fields.

Finally, some institutions in the advanced countries do make use of 'Faraday Cage' to minimise this evil act. This is a metal built into the walls of the examination hall to block electro-magnetic waves. It hampers the free flow of mobile networks and signals. In addition, it deactivates the possibilities of text messaging as long as the examination lasts.

\section{PROSPECTS OF USING TECHNOLOGIES}

If technologies are adopted effectively, the University would derive the following benefits:

First, less manpower would be used to carry out the invigilation. As an example, during the just concluded General Studies Courses Examination for GSP $1201 / 2201(2017 / 2018$ session), the Unit utilised about 90 (ninety) invigilators across the five faculties to invigilate this examination involving a little bit over 3,000 candidates. Ideally, if the CCTV camera is in place, and a big hall was made available, only five or less lecturers could effectively carry out this invigilation without stress. The remaining 85 lecturers would be involved in more profitable ventures, such as carrying out administrative duties, or, be in the field embarking on research works.

Secondly, it is economical in the long run. This is because if the Computer Based Test is adopted in organising such an examination for close to 3,000 students, the cost of printing 8-page objective testitem examination questions for such number of students, time spent in collation and other logistics, could have been averted. Furthermore, a lot of manhours was used in settling down to commence the examination in the two campuses. Related to this is the cost of buying refreshments for all the invigilators, travels, risk of carrying question papers and transporting it across the sites, and other logistics.

In addition, if technology is used, there may be a need to relieve Departmental, Faculty and Senate Central Examination Committees of this duty, and thereby using such time on Administrative duties. The Committees at each level usually meet at least three times, before concluding their reports. Related to this task is the security of the lives of the panel members. At times, they do receive threat letters, hidden mobile number phone calls, coded messages or information from anonymous people telling them to watch the kind of judgement to give, else, they and their family members would need to pay dearly for their actions. Most Faculty members are not always anxious to serve in this Committee, at either Departmental, Faculty or Central level. If technology is adequately applied, that Committee may be scrapped, thereby bringing sanity into the system.

Furthermore, if technology is applied, and examination misconduct is reduced drastically, the image of the University is enhanced, thereby promoting our integrity and honour. The University would be a force to be reckoned with in and abroad, as an institution of moral uprightness.

Remote invigilation would become part and parcel of the system. The stress of 'chasing' lecturers to go to examination halls for invigilation would be minimised. Since invigilation would be stress- free, lecturers would be more willing to participate in the invigilation exercise.

Finally, students would become more serious with their studies. They would study harder to excel. Students are encouraged to cheat because they have discovered that there are loop holes within the system during the planning and execution of the conduct of the examinations.. Also, the students have realised that effective machinery are not put in place to check them when entering the examination halls. The moment the students are fully aware that the metal detectors would see their technological devices beneath their clothing, and were barred from going to the examination hall with it, at the next available paper, he/she will not make an attempt to sneak an electronic gadget into the examination hall. 


\section{CHALLENGESTO INTEGRATING TECHNOLOGIES IN TO EXAMINATIONS}

The first major challenge is resistant to change. Lots of University lecturers, administrators and staff belong to the 'traditionalist school of thought', who does not believe in change, but just to maintain the status quo. They do believe that the system must continue to do things, they way it has been done for ages, and how, they met it. They have phobia for anything called 'technology', even, if it is something that they can adapt to easily.

The other challenge is related to funding. Institutions of today (including YMSUK), are battling with the issue of funding. Universities now need to look inwards to generate revenue, which is not really forthcoming. Paying the salaries of staff is now problematic for some state Universities, and the Federal Government has joined this wagon. It is pathetic to state that some State Governments are owing staff salaries up to fifteen months in arrears, with little or no hope in sight of paying the backlogs.

Also, our technological awareness level in solving examination misconduct issue is very low, compared to the advanced countries. Most University managements do not believe or have the notion that the adoption of technology could be a panacea to solving problems relating to examinations misconduct.

In addition, there is the problem of connectivity and network issues. Since some of these gadgets use servers, it would not be surprising if there is server connectivity problem during the conduct of examinations. When the Computer Based Examination is being conducted, there might be server connectivity problem, power failure, and simultaneously, the generator might also break down. Hence, the entire examination would become frustrating and messy.

Finally, there is the issue of maintenance. If these devices are bought, some (e.g. handheld metal detectors) can be misplaced or not located when needed. These equipment might be mis-used that after the first year of procurement and utilization, the continuous usage would become history.

\section{SUGGESTIONS}

Based on what have been discussed regarding the prospects of technology integration into invigilation above, one can deduce that the University needs to shift base from the traditional approach being used to check examinations misconduct to a modern approach.

Frankly speaking, it is possible for the University in particular and other Nigerian Universities in general to adopt the use of technologies to curb examinations misconduct, despite the challenges (most especially funding), listed above. This is because most of these technologies and gadgets are quite cheap to acquire. The stress that invigilators do go through is far more 'expensive' than the cost of some of these gadgets. In addition, the number of man-hours been wasted are quite unquantifiable compared to the benefits to be derived from adopting technologies.

Firstly, there is a need to sensitise the staff and the Management regarding the benefits to be derived from utilising technologies, and also the need to deviate from the existing norm. The Management and Information Science (MIS) Unit of the University can organise a short orientation and training on this.

In addition, the University should plan towards adopting the use of CBT examinations for examining large class courses e.g. General Studies. This is being done in most Universities. As a matter of policy (so as to meet standard and quality) in some Nigerian Universities, the Management has advised that where the number of candidates who registered for a course, exceeds a total number of one hundred (most especially Level 100 and 200), the use Computer Based Testing for examinations purpose should be adopted. This would reduce the problem of cheating, missing scripts, missing results, lateness in getting results etc, which are all the problems associated with large classes.

Closed Circuit Television (CCTV) cameras can be installed in the Tertiary Education Trust Fund (TETFUND) Sponsored Main University Library documentation section hall which the University do use for conducting Post-Unified Tertiary Matriculations Examinations and General Studies Examinations courses. This would serve as a dual purpose of curbing examination misconducts menace, as well as ensure that the books are under surveillance to avert theft or mutilation.

Electronic detectors which is quite cheap (about N47,000 each) can be purchased for use during 
examinations. Each department should be able to fund at least one of these from the Departmental Teaching and Learning (DTLC) Fees allocated to them for running their Departments from the University vote. Furthermore, hand held metal detectors are quite cheap to acquire. The University can fund the purchase of lots of these from the Students' Examination dues, which constitutes part of the school fees, paid by the students. If these cannot be purchased due to one reason or the other, some security service companies do hire it out at a token on daily basis for those who needed them.

In addition, the MIS Unit should be well equipped to have some remote-controlled signals and terminals in place to block the free flow of radioactive signals in and around the examination venues. The University can foot the bill of this service from the Computer Service Charges, which is part of the School fees been paid by the students. This is important because during the course of invigilation, few lecturers do concentrate on using their mobile phones to receive calls, play games, be on facebook, whatsapp, twitter etc, at the expense of actually carrying out the duties expected of them.

Finally, it is imperative for the University to sponsor the MIS staff for training, either locally or abroad on the use of some of these technologies. On return, they would also in turn train the invigilators and other stakeholders that are involved in the conduct of examinations in the University. This is very important as a means of achieving effective utilisation of these gadgets.

\section{CONCLUSION}

It has been realised that the malady that examination misconduct has caused in the society in general and tertiary institutions in particular seems incurable. Most citizens (parents, teachers, administrators, secretarial staff, supervisors and other stakeholders) had in one way or the other contributed to this educational malaise.

As a result, there is a need to look for a permanent solution if the educational tertiary sector is to be reckoned with. Certainly, this menace has affected the quality and type of certificates that tertiary institutions are awarding .The outcome of this is that Universities outside Nigeria do query the certificates being awarded to Nigerian graduates. This is because of the perception of our educational and academic systems.
Closely related to this is that employers in Nigeria do give priority to paper qualifications, rather than skill acquisition and competence to do the work.

This paper therefore tries to revolutionise and bring changes into the way and manner that our examinations are being invigilated so as to bring sanity into the system. At this crucial period, there is a great need for change. The change is through the adoption and use of technologies to curb examination malpractice, using Yusuf MaitamaSule University, Kano, Nigeria, as a case study.

If the suggestions tabled in this paper are implemented, certainly, the issue of examination malpractice would be drastically reduced, fade away gradually, and soon become history, and the honour and integrity accorded to our tertiary institutions in Nigeria would be revitalised.

\section{REFERENCES}

1. Agbatogun, A. O. (2007). Uses and Misuses of ICT in Examination Malpractices: Nigeria at a glance. Journal of African Educational Research Network.Vol.7 (2).Pp 175-183

2. Ajelabi, P. A. (2018). "Passing University's Semester Examinations in Flying Colours Without Involvement in Examinations Misconduct", A Seminar Paper Presented at the Faculty of Education, Umaru Musa Yar'adua University, Katsina , on $19^{\text {th }}$ June, 2018

3. Akpor, C. And Akpor, J. (2006). Assessment and Causes of the effects of examination malpractice at the tertiary level of Nigerian Educational System. Journal of the Nigerian Society for Educational Psychologists. Vol. 4(2). Pp 346-356

4. Anzare, S. J. (2014). Trends in Examination Malpractices in Nigerian Educational System and its effects on the Socio-Economic and Political Development of Nigeria., Asian Journal of Humanities and Social Science, Vol.2 (3)

5. Awanbor, D. (2004). Examination Malpractice and the degenerative effects on quality of Education. African Journal of Education . Vol9 (2)

6. Curran, K. Middleton, G. And Doherty, C. (2011).Cheating in Examinations with Technology. International Journal of Cyber Ethics in Education. Vol.1 (2)

7. Ijaiya N.Y.S. (2004). Agents of Malpractice in Nigerian Public Examinations: The Strongest 
Link. Nigerian Journal of Educational Research and Evaluation. Vol.5 (1). Pp 55-62

8. Issa, A.O. (2006). The impact of cultism and examination malpractice on the quality of education in the $21^{\text {st }}$ Century. Centre for Continuing Education, Federal Polytechnic, Offa. Pp 1-11

9. Maduemeza, M.M. (1998). Examination Malpractice in the S.S.C.E.: Current Trends, Problems and Prospects. Paper presented at the W.A.E.C. monthly Seminar

10. Ndifon, J.C. (2012). Public Examinations in Nigeria: Human Rights Perspective. British Journal of Arts and Social Science.Vol5 (2), pp 1-
11. Northwest University, Kano (2016); Northwest University Kano Students' Handbook. Kano. D\&P, Press Limited

12. Onuka, A.O.U and Amusan, M.A. (2008) .Causes, effects and probable solutions to examinations malpractice: A case of the W.A.E.C. in Abeokuta. Ghana Jourole in curbing examination malpractice journal of Teaching. Vol1 (8), pp 1-8

13. Onuka, A.O.U. and Durowoju (2011).Stakeholders' role in curbing examination malpractice in Nigeria. International Journal of Economy, Management and Social Sciences. Vol.2 (6) pp32-348 12 